\title{
UTILIZATION OF SAS LANGUAGE FOR MODELING THE ROCK BED PERFORMANCE
}

**Ezzat A. Abed EL-Ghaffar, ** Khiery M. Ismail , *Rashwan M. A.

\begin{abstract}
Heated air by solar collector has high variation in temperature because it is depend on time. Therefore, a rock-bed was used to regulate the air temperature and to damp out the large fluctuation of air temperature, although it causes a change in the phase and the amplitude temperature of the inlet air. The rock-bed could be used then to store day-heat for night use.

The purpose of this paper was to mathematically model the rock-bed performance using SAS language. This modeling utilizes; (1) rock-bed characteristics, (2) Fourier series, and (3) statistical procedures for predicting the outlet air temperature. A computer program was developed to achieve this purpose. An air flow of $4.66 \mathrm{~m}^{3} / \mathrm{min}$ was used to test the computer model and air temperatures at 0, 0.375, and $0.70 \mathrm{~m}$ of the rock bed height were recorded by time for $24 \mathrm{~h}$.

It was found that Fourier series was more efficient for predicting the air temperature at any vertical location of the rock-bed. The correlation coefficient using the rock-bed characteristics and Fourier series was 0.905 for predicting the outlet air temperature. The determination coefficients were found to be above 0.98 between observed and predicted air temperatures at any vertical location of the rock-bed.
\end{abstract}

\section{INTRODUCTION}

renewable energy-based on air heating system that does not
require a conventional auxiliary heater, can still meet a daily
load fraction exceeding $90 \%$ and supply hot air at a steady temperature and flow rate continuously for 24 hours a day (Augustus and Kumar, 2007).

\footnotetext{
**Prof. Agric. and Biosystems Eng. Dept., Fac. of Agric. (Chatby), Alexandria University.

*Assis. Prof. Agric. and Biosystems Eng. Dept., Fac. of Agric. (Chatby), Alexandria University.
} 
The utilization of air-rock or gravel packed beds is very important for heating or cooling a fluid by passing an air flow through it. Rocks are the materials, which are loosely packed in a store, take or give up heat from the air and have high energy storage capacity (Paksoy et al., 1995 and Chandra and Willits, 1981). The rock bed stores the thermal energy during the daytime and supplies heat during off-sunshine hours during day and night (Augustus and Kumar, 2007). Rock-bed is also considered to have the required characteristics such as higher thermal conductivity than those of water and phase change materials, rapid heat transfer, low cost and long life (Chandra et al., 1981 and Garzoli, 1989). The rock-beds are, in different meaning, used to damp out the large fluctuations of air temperature occurred when air is heated by a solar air collector or to alter the phase relationship between the input and output temperature (Smith et al., 1984). The rock-bed system kept the inside air temperature higher than that of outside air at night, even in an overcast day following a clear day (Ahmet Kürklü, 2002).

As the solar energy is intermittent, it needs to be stored in clear days to use the energy stored for heating at night (Bouhdjar et al., 1996 and Walton, et al., 1979).

Besides water and soil itself as the solar energy storage medium, 20-150 $\mathrm{mm}$ rocks are usually utilized to serve the same purpose (Santamouris, et al., 1994 and Bredenbeck, 1984).

Various researches showed that the rock-bed system could achieve an inside air temperature $4-20{ }^{\circ} \mathrm{C}$ higher than the outside air, in combination with a variety of energy conservation methods (Bouhdjar et al., 1990), and such systems could supply $20-70 \%$ of the annual heat requirement (Bredenbeck, 1987). Solar energy storage efficiencies of rock-bed systems varied from 8\% to 19\% (Bouhdjar et al., 1996 and Willits and Peet, 1987).

The response of the rock-beds to a periodic temperature variation has been studied by many researchers. An analytical solution to the output temperature of a packed bed exposed to a step input temperature was generally attributed to Schumann, (1929). Lattman and Sliva, (1970) modified Schumann's model to be applicable in the region of small Reynolds numbers. Hughes et al., (1976) developed a thermal model 
to simulate solar heating systems where air is the transfer fluid through a packed gravel bed energy storage system. Riaz, (1977) presented a simple one-dimensional single phase conductivity model for transient analysis of a packed bed which accounts for the fluid convection motion, the air- rock heat transfer, axial bed conduction, and internal particle conduction in which air and rock are at the same temperature. Eshleman et al., (1977) developed a numerical model of heat transfer in rock beds. Fujii, (1977) performed a theoretical analysis concerning the behavior of heat storage capacity in pebbles and spheres exposed to a fluid with a periodic temperature variation.

A mathematical model was also developed to predict the discharge air temperature variation with time when rock bed storage was exposed to steady periodic air flow with sinusoidal temperature (Abdel-Ghaffar, 1980 and 1996). The model was derived from the fundamentals of heat and mass phenomena. A partial differential equation for the air temperature at any position at any time in the rock bed was developed as:

$$
\mathrm{C} \frac{\partial \mathbf{T}_{\mathrm{f}}}{\partial \mathrm{X}}+\mathrm{D} \frac{\partial^{2} \mathbf{T}_{\mathrm{f}}}{\partial \mathrm{X} \boldsymbol{t}}+\mathbf{E} \frac{\partial \mathbf{T}_{\mathrm{f}}}{\partial t}=\mathbf{O}
$$

Where; $\mathrm{C}=\mathrm{q} \rho_{\mathrm{f}} \mathrm{C}_{\mathrm{f}}$,

$$
\begin{aligned}
& \mathrm{E}=\mathrm{A}_{\mathrm{s}} \rho_{\mathrm{s}} \mathrm{C}_{\mathrm{s}}, \\
& \mathrm{D}=\left(\mathrm{A}_{\mathrm{s}} \rho_{\mathrm{s}} \mathrm{C}_{\mathrm{s}}\right)\left(q \rho_{f} C_{f}\right) / h_{v}=(E)(C) / h_{v}
\end{aligned}
$$

The volumetric heat transfer coefficient, $\mathrm{h}_{\mathrm{v}}$, was obtained from Packer et al., (1980) and Abdel-Ghaffar, (1996) as follows:

$$
h_{v}=2.12\left(\frac{G}{D_{p}}\right)^{0.543}
$$

The partial differential equation was developed using three fundamental heat equations which explain the heat exchange between the air and solids as follows:

1- Energy equation for the air moving through the bed rock (x) representing the thermal and physical properties of the heated air, 
2- Energy gain or loss to or from the solids (x) representing the physical and thermal properties of the solids,

3- The exchange of heat or energy transfer between the moving air and the solid including temperature of solids,

4- To develop one phase model energy balance only for air instead of two phase model (air and solids), it is important to eliminate the solid temperature by differentiate the partial differential equation with respect to the time $(\mathrm{t})$ leading to the second order partial differential equation for the air temperature at any position $(\mathrm{x})$ and at any time $(\mathrm{t})$ in the limestone bed (Abdel-ghaffar, 1980, Schuman, 1929 and Wylie, 1975).

Wylie, (1975) presented a different model that relates the vertical height $(\mathrm{x})$ and time $(\mathrm{t})$ to the air temperature $\left(\mathrm{T}_{\mathrm{f}}\right)$ at any location in the rock-bed. This model can be expressed as follows:

$$
\mathrm{T}_{\mathrm{f}}(\mathrm{x}, \mathrm{t})=T_{\text {mean }}+\mathrm{T}_{\mathrm{amp}} \mathrm{e}^{-\mathrm{AX}} \sin (\omega \mathrm{t}-\mathrm{BX})
$$

Where; $\mathrm{T}_{\mathrm{amp}}$ is the amplitude of the sinusoidal temperature function, $\mathrm{A}$ is the exponential decay coefficient, per unit length and B is the phase lag angle radian per unit length.

By differentiation of the Wylie equation's with respect to the position (x) and time $(\mathrm{t})$ we get the following equations:

$$
\begin{aligned}
& \frac{\partial T_{f}}{\partial x}=-\mathrm{T}_{\mathrm{amp}} \mathrm{Ae}^{-\mathrm{AX}} \sin (\omega \mathrm{t}-\mathrm{B} \mathrm{X})-\mathrm{T}_{\mathrm{amp}} B e^{-A X} \cos (\omega t-B X) \\
& \frac{\partial^{2} T_{f}}{\partial x \partial t}=-\mathrm{T}_{\mathrm{amp}} \mathrm{Ae}^{-\mathrm{AX}} \omega \cos (\omega \mathrm{t}-\mathrm{BX})-\mathrm{T}_{\mathrm{amp}} B e^{-A X}(-\omega) \sin (\omega t-B X)(5) \\
& \frac{\partial T_{f}}{\partial t}=\mathrm{T}_{\mathrm{amp}} \mathrm{e}^{-\mathrm{AX}} \omega \cos (\omega \mathrm{t}-\mathrm{BX})
\end{aligned}
$$

Substituting with the previous derivatives in the equation (1) with an identity for all $\mathrm{x}$ and $\mathrm{t}$, since $\sin (\omega \mathrm{t}-\mathrm{BX})$ and $\cos (\omega t-\mathrm{BX}) \neq 0.0$, then the coefficients of sine and cosine must be zero, so the coefficients $\mathrm{A}$ and $\mathrm{B}$ 
could be determined and expressed in terms of the bed characteristics and the air velocity as follows (Abdel-Ghaffar, 1980):

$$
\mathbf{A}=\frac{\omega^{2} \mathbf{D} \mathbf{E}}{\omega^{2} \mathbf{D}^{2}+\mathbf{C}^{2}} \quad \text { and } \quad \mathbf{B}=\frac{\omega \mathbf{C} \mathbf{E}}{\omega^{2} \mathbf{D}^{2}+\mathbf{C}^{2}}
$$

Where $\omega$ is the angular velocity of sinusoidal temperature variation imposed on incoming air temperature, and it was determined as follows: $\omega=2 \pi / \mathrm{p}$, where $\mathrm{p}$ is the period of oscillation in $\mathrm{rad} / \mathrm{hrs}$.

In this paper, a computer model was developed using SAS language to improve the prediction of limestone-bed performance. This program with the high capability of SAS procedures will improve Ezzat's model where 6 series of sine and cosine terms are used instead of 4 series in Ezzat's model. Thus, the objectives of this paper were then to:

1- Derive the system characteristics of limestone bed designed by Ezzat, (1980) that control the outlet air temperature from the limestone bed as a function of the air flow input to the system. These characteristics were mainly, the phase lag angle and the exponential decay coefficients.

2- Model the air temperature through the limestone bed mainly at; inlet gate, center of the bed height and outlet gate using Fourier series.

3- Develop the models that predict the outlet air temperature using the system characteristics and the inlet air temperature at two levels of air flow.

\section{MATERIALS AND METHODS}

The experimental unit consisted of a solar air heater and limestone bed. The unit was constructed at Agricultural and Biosystems Engineering in Alexandria University to obtain actual test data. It consisted of a wooden frame of $2.5 \mathrm{~m}$ long, $1.1 \mathrm{~m}$ wide and $0.265 \mathrm{~m}$ high. The aperture area of the solar air collector exposed to sun rays is $2.0 \mathrm{~m}^{2}$ (2.0 m long and one meter wide). A flat galvanized sheet metal with a thickness of one $\mathrm{mm}$. was installed fixed inside the wooden frame. The absorbing surface plate was painted by a black material to increase the solar collection efficiency. A glass sheet of $3 \mathrm{~mm}$ thick was placed on the wooden frame at a distance of $12 \mathrm{~cm}$. to form an upper passage was formed by the 
absorbing surface and an insulated bottom which was made of wood at a distance of $10 \mathrm{~cm}$. the moving air stream picks up head from both sides of the absorber. The solar collector was connected to the rock bed storage system at one end and to a centrifugal fan at the other end through a set of pipes. The solar air heater was oriented toward the south direction. It was tilted by a movable steel frame. The tilt angle was about 20 degrees from the horizontal plane. 11 joints were sealed carefully to minimize leakage. Fig. (1) shows the cross section of experimental unit of solar rock bed storage system.

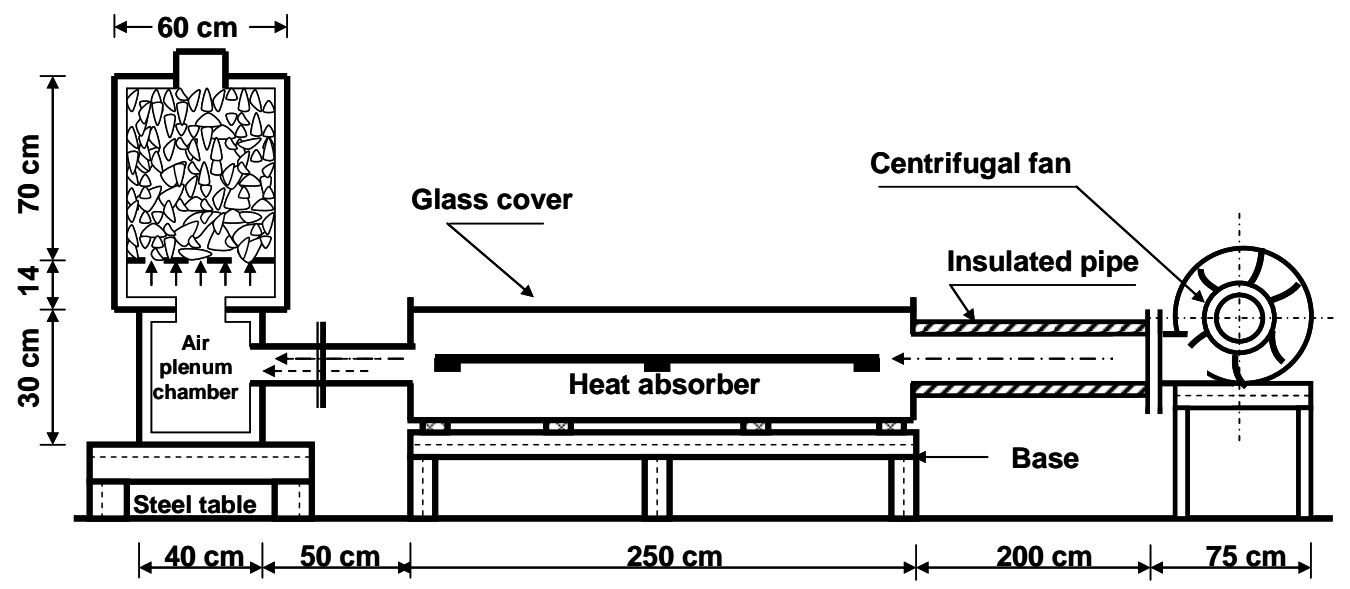

Figure (1): A diagrammatic sketch of the solar rock-bed storage system

\section{EQUIPMENT}

\section{1- Rock bed:}

A packed bed was constructed of $1 \mathrm{~mm}$ thick galvanized sheet with inside diameter of $1.13 \mathrm{~m}$ and a height of $1.02 \mathrm{~m}$ inlet chamber of same dimension was connected to the bed section. The bed was insulated with $20 \mathrm{~mm}$ thick of an insulated material. Limestone was placed in the bed and supported by steel plate of $20 \mathrm{~mm}$ holes at the bottom of the rock bed.

\section{2- Solar air heater:}

The solar air heater was constructed of $1 \mathrm{~mm}$ black galvanized sheet metal with $1.0 \mathrm{~m}$ wide and a length of $2.0 \mathrm{~m}$. The aperture area of solar air heater was $2.0 \mathrm{~m}^{2}$. A wooden frame with dimensions of $2.5 \mathrm{~m}$ long, 
$1.1 \mathrm{~m}$ wide and $0.265 \mathrm{~m}$ high was used to fix both solar energy a absorber and glass sheet. More details of solar air heater were presented by Abdel-Ghaffar, (1986).

\section{3- Centrifugal fan:}

A Centrifugal fan was to supply air to the solar air heater and rock bed that were connected together by a $0.20 \mathrm{~m}$ inside diameter metal tube. This fan was connected to the solar collector by metal tube of $0.20 \mathrm{~m}$ inside diameter and $2.0 \mathrm{~m}$ long air flow adjusted by two gates constructed directly at fan exit.

\section{4- Instrumentation:}

The heated air temperature passing through the solar air heater and rock bed were measured at half hour interval time. The air flow rate was measured by a Pitot tube and an inclined manometer that had accuracy of 0.005 inch water.

\section{PROCEDURE}

Before staring the test, the equivalent spherical diameter, the true and apparent density of the material, and the void fraction of the bed were all measured. The equivalent spherical diameter, Dp, of the particles was calculated from the following formula suggested by Löf and Hawley, (1948):

$$
\mathrm{D}_{P}=\left[\frac{6}{\pi} \frac{\text { net volume of particles in } \mathrm{cm}^{3}}{\text { number of particles }}\right]^{\frac{1}{3}}
$$

The void fraction, e was determined from the following relation:

$$
\mathbf{e}=\mathbf{1}-\boldsymbol{\rho}_{\mathrm{b}} / \boldsymbol{\rho}_{\mathrm{s}}
$$

Where, $\rho_{b}$ is the bulk density of limestone in bed and $\rho_{s}$ is the solid density or true density of limestone. The bulk density of limestone in bed was measured by weighing the limestone in the test section divided by the volume of the bed under test (Löf and Hawley, 1948).

About $830 \mathrm{~kg}$ of limestone were placed in the bed up to $0.70 \mathrm{~m}$ depth. The equivalent spherical diameter of stone was determined. The particles and apparent density of the limestone as well as the void fraction of the material inside the bed were also determined according to the methods published by Smith et al., (1984) and Abdel-Ghaffar, (1986). Table (1) 
shows the physical properties of limestone and the characteristics of rock- bed used in this study.

Heated air temperatures were measured in the rock bed at $0,0.375$ and $0.70 \mathrm{~m}$. above the bed bottom. Temperature was recorded every half hour for 2-3 days at the air flow rate of $4.66 \mathrm{~m}^{3} / \mathrm{min}$.

Statistical procedures were used to predict the temperatures $T_{1}, T_{2}$ and $T_{3}$ for the three heights mentioned above, respectively. This prediction was based on fitting the observed data to expansion of Fourier series.

At least the first six harmonic terms for "sin and cos" were considered to give an accurate prediction for each function. Basically, the general temperature function takes the following expression:

$$
\begin{aligned}
F\left(t_{i}\right) & =A_{0}+A_{1} \cos (\omega t)+A_{2} \cos (2 \omega t)+A_{3} \cos (3 \omega t)+\ldots+A_{6} \cos (6 \omega t) \\
& +B_{1} \sin (\omega t)+B_{2} \sin (2 \omega t)+B_{3} \sin (3 \omega t)+\ldots .+B_{6} \sin (6 \omega t)
\end{aligned}
$$

Where $\mathrm{A}_{0}, \mathrm{~A}_{1}, \mathrm{~A}_{2}, \mathrm{~A}_{3}, . ., \mathrm{A}_{6}$, and $\mathrm{B}_{1}, \mathrm{~B}_{2}, \mathrm{~B}_{3}, \ldots, \mathrm{B}_{6}$ are the Fourier series coefficients. The statistical methods provide the estimate values of these coefficients with the significance test of each.

Table (1): Characteristics of limestone bed and physical properties of crushed limestone.

\begin{tabular}{lccc}
\hline \multicolumn{1}{c}{ Characteristics } & Symbol & Units & Value \\
\hline 1-Rock-Bed Characteristics & & & \\
Diameter & $\mathrm{d}$ & $\mathrm{m}$ & 1.13 \\
Height & $\mathrm{H}$ & $\mathrm{m}$ & 0.70 \\
Volume & $\mathrm{V}$ & $\mathrm{m}^{3}$ & 0.702 \\
Cross Sectional Area & $\mathrm{a}$ & $\mathrm{m}^{2}$ & 1.003 \\
2-Solid Characteristics & & & \\
Limestone weight & $\mathrm{m}$ & $\mathrm{kg}$ & 831.51 \\
Solid density & $\rho_{\mathrm{s}}$ & $\mathrm{kg} / \mathrm{m}^{3}$ & 2435.5 \\
Diameter of particle & $\mathrm{D}_{\mathrm{p}}$ & $\mathrm{cm}$ & 4.791 \\
Void fraction & $\mathrm{e}$ & - & $51.5 \%$ \\
Mean length of particle & - & $\mathrm{cm}$ & 7.72 \\
Mean width of particle & - & $\mathrm{cm}$ & 5.35 \\
Mean thickness of particle & - & $\mathrm{cm}$ & 3.63 \\
\hline
\end{tabular}


Table (2) shows the physical and thermal properties of limestone and solar heated air required for predicting the temperature distribution at the outlet of the limestone bed. It shows also the values of all variables input to the model for only the low air flow $\left(4.66 \mathrm{~m}^{3} / \mathrm{min}\right)$.

Using the design characteristics of the rock-bed including the coefficients; A, and B as shown in Table (2), a new Fourier series coefficients were computed in order to predict the temperature of air at any height and time. A computer program using language SAS was developed to estimate the new model of limestone performance to predict the temperature of air as a function of height and time. The program determines also the coefficients of A and B.

Table (2): The physical and thermal properties of limestone and solar heated air required for predicting the temperature distribution at the outlet of the limestone bed.

\begin{tabular}{lccc}
\hline Characteristics & Symbol & Units & Values \\
\hline Void fraction & $\mathrm{e}$ & - & 0.515 \\
Air mean temp. & $\mathrm{T}_{\text {mean }}$ & $\mathrm{C}^{\mathrm{o}}$ & 35 \\
Air density & $\rho_{\mathrm{f}}$ & $\mathrm{kg} / \mathrm{m}^{3}$ & 1.127 \\
Air specific heat & $\mathrm{C}_{\mathrm{F}}$ & $\mathrm{kJ} / \mathrm{kg} \cdot \mathrm{K}^{\mathrm{o}}$ & 1.007 \\
Length of rock bed & $\mathrm{L}$ & $\mathrm{m}$ & 0.7 \\
Air flow rate & $\mathrm{Q}$ & $\mathrm{m}^{3} / \mathrm{hr}$ & 280 \\
Solid area as \% of cross section & $\mathrm{A}_{\mathrm{s}}$ & $\mathrm{m}^{2}$ & 0.485 \\
Limestone density & $\rho_{\mathrm{s}}$ & $\mathrm{kg} / \mathrm{m}^{3}$ & 2435.5 \\
Limestone specific heat & $\mathrm{C}_{\mathrm{s}}$ & $\mathrm{kJ} / \mathrm{kg} \cdot \mathrm{K}^{\mathrm{o}}$ & 0.9085 \\
Equivalent spherical diameter & $\mathrm{D}_{\mathrm{p}}$ & $\mathrm{cm}$ & 4.714 \\
Superficial mass velocity per unit & $\mathrm{G}$ & $\mathrm{kg} / \mathrm{hr} \cdot \mathrm{m}^{2}$ & 320 \\
cross section of limestone bed & & & \\
Volumetric heat transfer coeff. & $\mathrm{h}_{\mathrm{v}}$ & $\mathrm{kJ} / \mathrm{hr} \cdot \mathrm{m}^{3} \cdot \mathrm{C}^{\mathrm{o}}$ & 3732.9 \\
Time & $\mathrm{t}$ & $\mathrm{hr}$ & - \\
Periodic of oscillation & $\mathrm{p}$ & $\mathrm{hr}$ & 24 \\
Heat capacity of air & $\mathrm{C}$ & $\mathrm{kJ} / \mathrm{hr} \cdot \mathrm{C}^{\mathrm{o}}$ & 317.8 \\
Heat capacity of limestone & $\mathrm{E}$ & $\mathrm{kJ} / \mathrm{m} \cdot \mathrm{C}$ & 1073.1 \\
C*E/h & $\mathrm{D}$ & $\mathrm{kJ} / \mathrm{m} \cdot \mathrm{C}$ & 91.35 \\
Angular velocity & $\omega$ & $\mathrm{rad} / \mathrm{hr}$ & 0.2618 \\
Exponential decay coefficient & $\mathrm{A}$ & $1 / \mathrm{m}$ & 0.39299 \\
Phase lag coefficient & $\mathrm{B}$ & $\mathrm{rad} / \mathrm{m}$ & 0.68614 \\
\hline
\end{tabular}




\section{RESULTS AND DISCUSSION}

Figure 2 shows the flow chart of the computer program used for predicting the limestone bed performance. The program utilizes SAS language and Fourier series in order to determine the temperature distribution at the three heights mentioned above and to find the coefficients A and B.

The program also prints the predicted values of the temperatures T1, T2 and T3 with the related correlation coefficient. The output of this program is shown in Tables (3) through (11).

Tables (3), (4) and (5) show the statistical analysis of T1. Table (3) gives the results of the general linear models (GLM) procedure of the dependent variable $\mathrm{T} 1$ and Table (4) gives the test of significance of the variables of Fourier series of T1 while Table (5) gives the estimate values and its significance test of the Fourier series variables of T1. As shown in Table (3), the determination coefficient is above 0.99. The estimate values of first twelve harmonic terms of Fourier series are later used by the computer program to predict the temperature distribution of the limestone at the outlet.

Table (3): The results of GLM procedure of the dependent variable T1.

\begin{tabular}{|c|c|c|c|c|c|}
\hline \multicolumn{6}{|c|}{$\begin{array}{l}\text { General Linear Models Procedure of Dependent Variable: } T 1 \\
\text { Number of observations in data set }=145\end{array}$} \\
\hline Source & DF & Sum of Squares & Mean Square & F Value & $\operatorname{Pr}>\mathbf{F}$ \\
\hline Model & 12 & 8030.309 & 669.19242 & 3209.28 & 0.0001 \\
\hline Error & 84 & 17.515 & \multicolumn{3}{|l|}{0.20852} \\
\hline Corrected Total & 96 & \multicolumn{4}{|r|}{8047.82} \\
\hline $\begin{array}{l}\text { R-Square } \\
0.9978\end{array}$ & \multicolumn{2}{|c|}{ C.V. 1.531} & $\begin{array}{l}\text { Root MSE } \\
0.457\end{array}$ & \multicolumn{2}{|c|}{$\begin{array}{l}\text { Mean of T1 } \\
29.822\end{array}$} \\
\hline
\end{tabular}




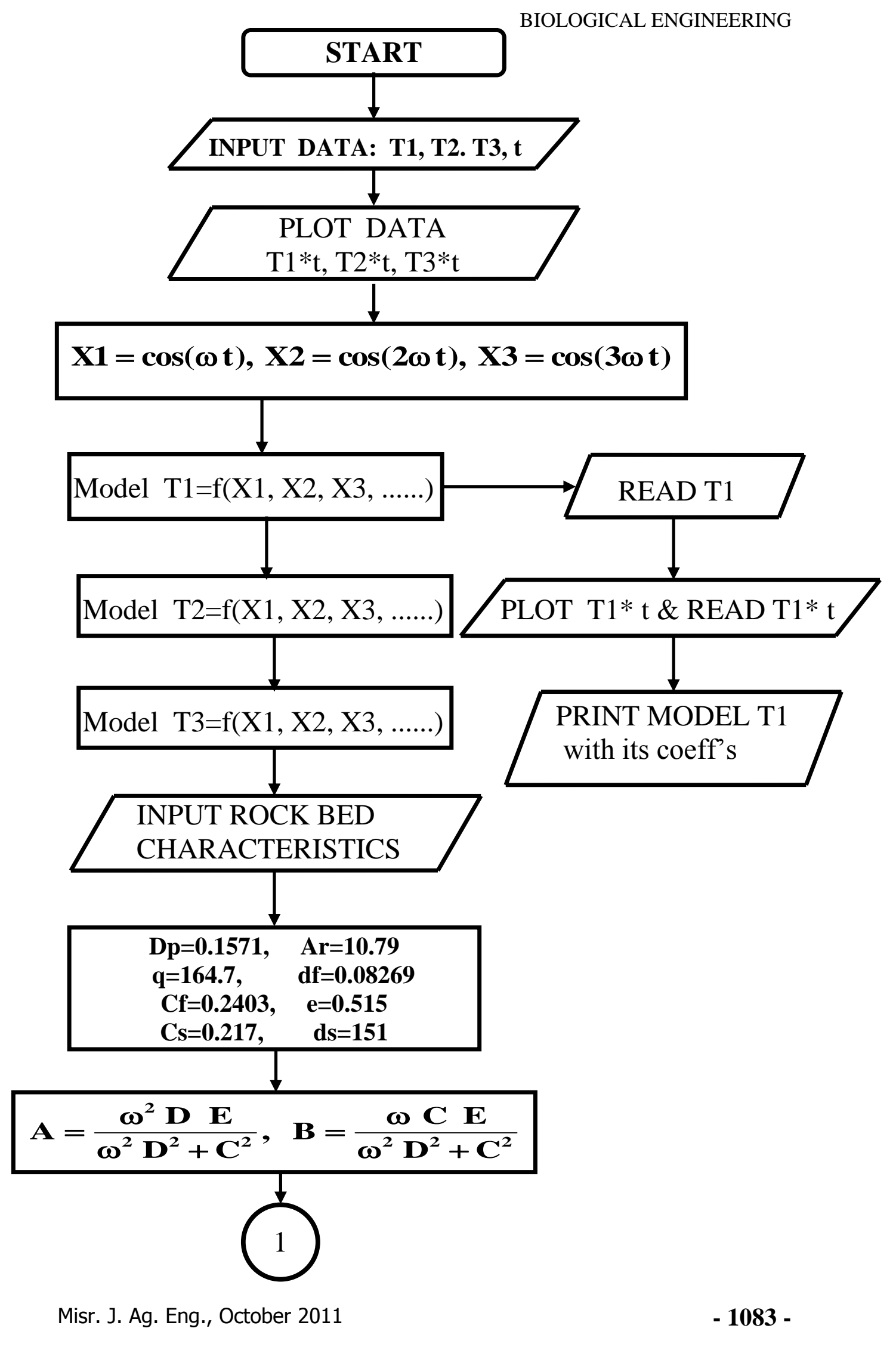




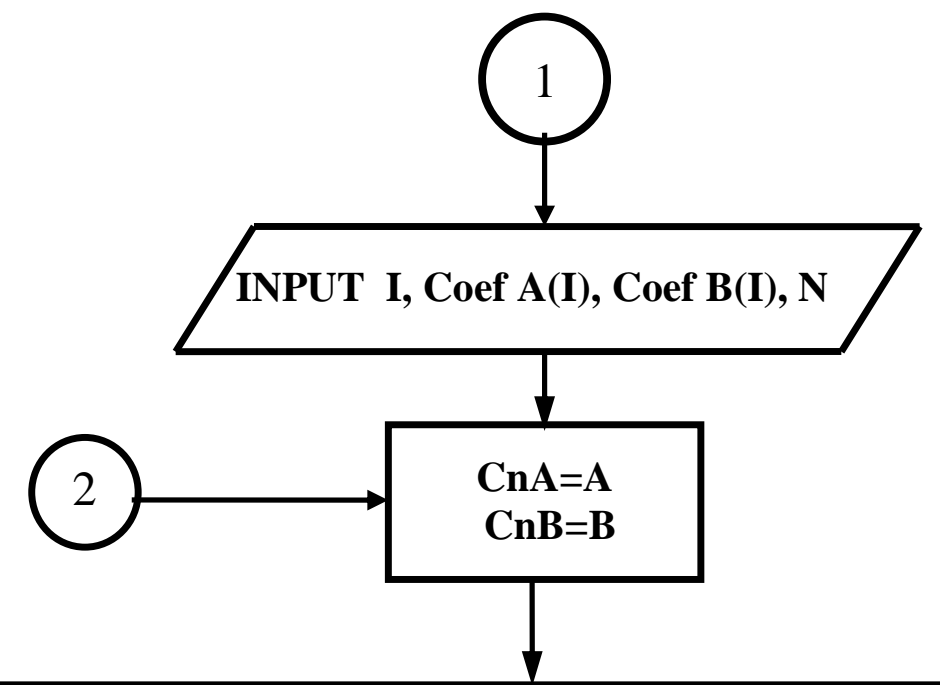

$$
\begin{aligned}
& \operatorname{Ca}(I)=\operatorname{coefa}(I) * \cos (\operatorname{cnb} * x) * \mathrm{e}^{-\operatorname{cna} a x}-\operatorname{coefb}(I) * \sin (\operatorname{cnb} * x) * \mathrm{e}^{-\operatorname{cna} a x} \\
& \operatorname{Cb}(I)=\operatorname{coefb}(I) * \cos (\operatorname{cnb} * x) * e^{-\operatorname{cna} a x}-\operatorname{coefa}(I) * \sin (\operatorname{cnb} * x) * e^{-\operatorname{cna} * x}
\end{aligned}
$$

Tout $=29.88+\operatorname{ca} 1 * \cos (1 * \omega t)+\operatorname{ca} 2 * \cos (2 * \omega t)+\operatorname{ca} 3 * \cos (3 * \omega t)+\operatorname{ca} 4 * \cos (4 * \omega t)+\ldots .$. $\operatorname{cb} 1 * \sin (1 * \omega t)+\operatorname{cb} 2 * \sin (2 * \omega t)+\operatorname{cb} 3 * \sin (3 * \omega t)+\operatorname{cb} 4 * \sin (4 * \omega t)+\ldots$.

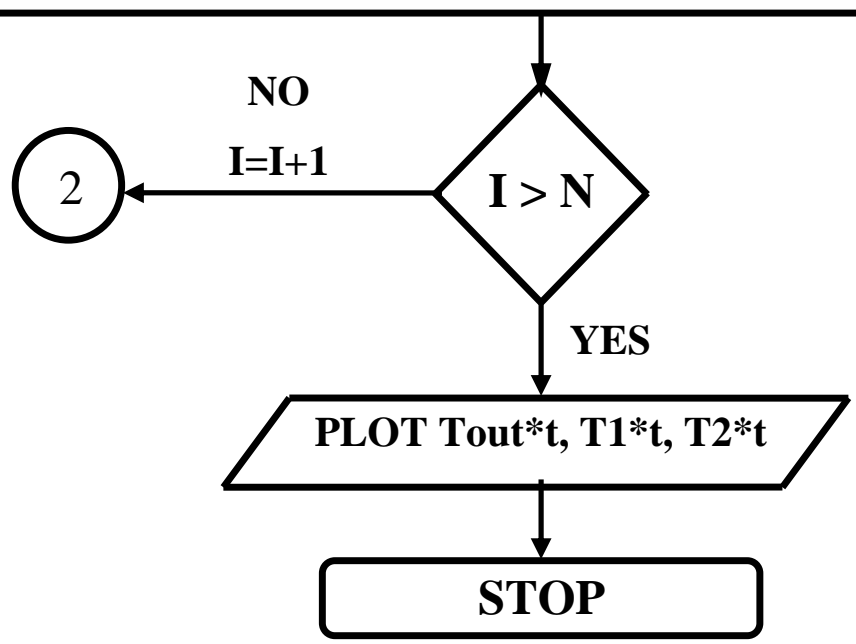

Figure (2): Flow chart of the computer SAS program used for predicting the limestone bed performance. 
Table (4): The test of significance of the variables of Fourier series of T1.

\begin{tabular}{llllll}
\hline Variable & DF & Type III SS & Mean Square & F value & Pr > F \\
\hline x1 & 1 & 7.78785 & 7.78785 & 37.35 & 0.0001 \\
x2 & 1 & 885.2738 & 885.2738 & 4245.55 & 0.0001 \\
x3 & 1 & 1.71247 & 1.71247 & 8.21 & 0.0053 \\
x4 & 1 & 17.4089 & 17.4089 & 83.49 & 0.0001 \\
x5 & 1 & 0.88160 & 0.88160 & 4.23 & 0.0429 \\
x6 & 1 & 2.12800 & 2.12800 & 10.21 & 0.0020 \\
x7 & 1 & 7082.25 & 7082.25 & 33964.73 & 0.0001 \\
x8 & 1 & 14.6874 & 14.6874 & 70.44 & 0.0001 \\
x9 & 1 & 0.44872 & 0.44872 & 2.15 & 0.1461 \\
x10 & 1 & 0.98588 & 0.98588 & 4.73 & 0.0325 \\
x11 & 1 & 0.18714 & 0.18714 & 0.90 & 0.3462 \\
x12 & 1 & 0.27395 & 0.27395 & 1.31 & 0.2550 \\
\hline
\end{tabular}

Table (5): The estimate values and its significance test of the Fourier series variables of $\mathrm{T} 1$.

\begin{tabular}{llllll}
\hline Parameter & Estimate & $\begin{array}{l}\text { T for H0: } \\
\text { Parameter=0 }\end{array}$ & Pr $>|\mathbf{T}|$ & $\begin{array}{l}\text { STD ERROR of } \\
\text { Estimate }\end{array}$ \\
\hline INTERCEPT & 29.88126 & 644.12 & 0.0001 & 0.04639 \\
X1 & -0.39909 & -6.11 & 0.0001 & 0.06530 \\
X2 & -4.25497 & -65.16 & 0.0001 & 0.06530 \\
X3 & -0.18714 & -2.87 & 0.0053 & 0.06530 \\
X4 & -0.59668 & -9.14 & 0.0001 & 0.06530 \\
X5 & -0.13427 & -2.06 & 0.0429 & 0.06530 \\
X6 & -0.20861 & -3.19 & 0.0020 & 0.06530 \\
X7 & 12.14690 & 184.30 & 0.0001 & 0.06591 \\
X8 & 0.55316 & 8.39 & 0.0001 & 0.06591 \\
X9 & 0.09669 & 1.47 & 0.1461 & 0.06591 \\
X10 & 0.14331 & 2.17 & 0.0325 & 0.06591 \\
X11 & 0.06244 & 0.95 & 0.3462 & 0.06591 \\
X12 & 0.07554 & 1.15 & 0.2550 & 0.06591 \\
\hline
\end{tabular}

Figure (3) shows the temperature distribution of the measured T1, T2, and $\mathrm{T} 3$ at rock-bed heights of $0.0,0.375$ and $0.7 \mathrm{~m}$ respectively for airflow rate of $4.66 \mathrm{~m}^{3} / \mathrm{min}$.

Tables (6) through (11) show the statistical analysis for T2 and T3 with the same manner as for T1. Figures (4), (5) and (6) show the 
temperature distribution of measured and predicted $\mathrm{T} 1, \mathrm{~T} 2$ and $\mathrm{T} 3$ respectively.

The correlation coefficient, $r$, between the measured $\mathrm{T} 3$ and predicted $\mathrm{T} 3$ (namely $\mathrm{T}_{\text {out }}$ ) using the computer model explained above by applying Fourier series technique and the design thermal characteristics of the limestone-bed was also shown in Table (12). It reached 0.90. The graph on Figure (7) shows the temperature distribution at the inlet (T1) and outlet (T3) of the rock-bed as well as the predicted temperature distribution $\left(\mathrm{T}_{\text {out }}\right)$. The computed coefficients $\mathrm{A}$ and $\mathrm{B}$ are shown in Table (2).

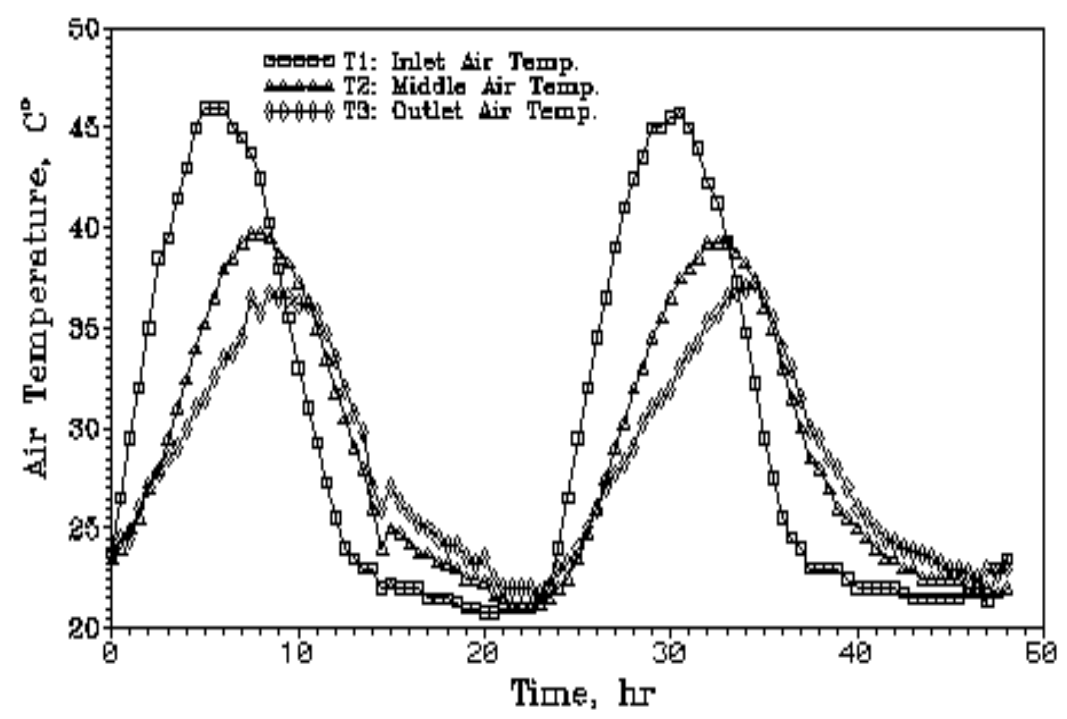

Figure (3): Temperature distribution; T1, T2, T3 at the inlet, middle height, and outlet of the limestone-bed respectively.

Table (6): The results of GLM procedure of the dependent variable T2.

General Linear Models Procedure of Dependent Variable: T2 Number of observations in data set $=\mathbf{1 4 5}$

\begin{tabular}{l|r|l|l|l|l}
\hline Source & DF & Sum of Squares & Mean Square & F Value & Pr > F \\
\hline Model & 12 & 3878.00266 & 323.16689 & 1024.62 & 0.0001 \\
\hline Error & 84 & 26.49363 & 0.31540 & & \\
\hline Corrected total & 96 & 3904.49629 & Root MSE 0.562 & T1 Mean 28.806 \\
\hline R-Square 0.9932 & C.V. & 1.9496 &
\end{tabular}


Table (7): The test of significance of the variables of Fourier series of T2.

\begin{tabular}{llllll}
\hline Variable & DF & Type III SS & Mean Square & F value & Pr $>$ F \\
\hline x1 & 1 & 1165.008 & 1165.008 & 3693.74 & 0.0001 \\
x2 & 1 & 92.487 & 92.487 & 293.24 & 0.0001 \\
x3 & 1 & 0.71636 & 0.71636 & 2.27 & 0.1355 \\
x4 & 1 & 0.4403 & 0.4403 & 0.14 & 0.7096 \\
x5 & 1 & 0.27801 & 0.27801 & 0.88 & 0.3505 \\
x6 & 1 & 0.09012 & 0.09012 & 0.29 & 0.5944 \\
x7 & 1 & 2475.473 & 2475.473 & 7848.67 & 0.0001 \\
x8 & 1 & 120.2065 & 120.2065 & 381.12 & 0.0001 \\
x9 & 1 & 4.68534 & 4.6853 & 14.86 & 0.0002 \\
x10 & 1 & 0.65762 & 0.65762 & 2.09 & 0.1525 \\
x11 & 1 & 0.35241 & 0.35241 & 1.12 & 0.2935 \\
x12 & 1 & 0.04941 & 0.04941 & 0.16 & 0.6933 \\
\hline
\end{tabular}

Table (8): The estimate values and its significance test of the Fourier series variables of $\mathbf{T} 2$.

\begin{tabular}{lcllll}
\hline Parameter & Estimate & $\begin{array}{l}\text { T for H0: } \\
\text { Parameter }=\mathbf{0}\end{array}$ & Pr $>|\mathbf{T}|$ & $\begin{array}{l}\text { STD ERROR of } \\
\text { Estimate }\end{array}$ \\
\hline INTERCEPT & 28.87259 & 506.05 & 0.0001 & 0.05706 \\
X1 & -4.8811 & -60.78 & 0.0001 & 0.08031 \\
X2 & -1.3753 & -17.12 & 0.0001 & 0.08031 \\
X3 & -0.1210 & -1.51 & 0.1355 & 0.08031 \\
X4 & -0.0300 & -0.37 & 0.7096 & 0.08031 \\
X5 & -0.0754 & -0.94 & 0.3505 & 0.08031 \\
X6 & 0.0429 & 0.53 & 0.5944 & 0.08031 \\
X7 & 7.1814 & 88.59 & 0.0001 & 0.08106 \\
X8 & -1.5825 & -19.52 & 0.0001 & 0.08106 \\
X9 & 0.3124 & 3.85 & 0.0002 & 0.08106 \\
X10 & -0.1170 & -1.44 & 0.1525 & 0.08106 \\
X11 & 0.08568 & 1.06 & 0.2935 & 0.08106 \\
X12 & 0.03208 & 0.40 & 0.6933 & 0.08106 \\
\hline
\end{tabular}

Table (9): The results of GLM procedure of the dependent variable T3.

General Linear Models Procedure of Dependent Variable: T3

Number of observations in data set $=145$

\begin{tabular}{l|r|l|l|l|l}
\hline Source & DF & $\begin{array}{l}\text { Sum of } \\
\text { Squares }\end{array}$ & Mean Square & F Value & Pr $>$ F \\
\hline Model & 12 & 2368.94082 & 197.41174 & 669.44 & 0.0001 \\
\hline Error & 84 & 24.77098 & 0.29489 & \\
\hline Corrected total & 96 & 2393.71180 & Root MSE 0.543 & T1 Mean 28.484 \\
\hline R-Square 0.99 & C.V. 1.906 &
\end{tabular}


Table (10): The test of significance of the variables of Fourier series of T3.

\begin{tabular}{llllll}
\hline Variable & DF & Type III SS & Mean Square & F value & Pr $>$ F \\
\hline x1 & 1 & 1189.675 & 1189.675 & 4034.27 & 0.0001 \\
x2 & 1 & 0.08315 & 0.08315 & 0.28 & 0.5968 \\
x3 & 1 & 6.18475 & 6.18475 & 20.97 & 0.0001 \\
x4 & 1 & 0.07562 & 0.07562 & 0.26 & 0.6139 \\
x5 & 1 & 0.44300 & 0.44300 & 1.50 & 0.2238 \\
x6 & 1 & 0.17830 & 0.17830 & 0.60 & 0.4390 \\
x7 & 1 & 1088.639 & 1088.639 & 3691.65 & 0.0001 \\
x8 & 1 & 55.32666 & 55.32666 & 187.62 & 0.0001 \\
x9 & 1 & 19.48454 & 19.48454 & 66.07 & 0.0001 \\
x10 & 1 & 0.76984 & 0.76984 & 2.61 & 0.1099 \\
x11 & 1 & 0.96219 & 0.96219 & 3.26 & 0.0744 \\
x12 & 1 & 0.17561 & 0.17561 & 0.60 & 0.4425 \\
\hline
\end{tabular}

Table (11): The estimate values and its significance test of the Fourier series variables of T3.

\begin{tabular}{llllll}
\hline Parameter & Estimate & $\begin{array}{l}\text { T for } \\
\text { Parameter=0 }\end{array}$ & Pr $>\mid$ T| & $\begin{array}{l}\text { STD ERROR of } \\
\text { Estimate }\end{array}$ \\
\hline INTERCEPT & 28.5402547 & 517.32 & 0.0001 & 0.05516899 \\
X1 & -4.93255592 & -63.52 & 0.0001 & 0.07765862 & \\
X2 & -0.04123728 & -0.53 & 0.5968 & 0.07765862 & \\
X3 & -0.35564668 & -4.58 & 0.0001 & 0.07765862 & \\
X4 & -0.03932694 & -0.51 & 0.6139 & 0.07765863 \\
X5 & -0.09518286 & -1.23 & 0.2238 & 0.07765863 \\
X6 & 0.06038520 & 0.78 & 0.4390 & 0.07765864 \\
X7 & 4.76235646 & 60.76 & 0.0001 & 0.07838119 \\
X8 & -1.07361141 & -13.70 & 0.0001 & 0.07838119 \\
X9 & 0.63712544 & 8.13 & 0.0001 & 0.07838118 \\
X10 & -0.12664232 & -1.62 & 0.1099 & 0.07838118 \\
X11 & 0.14158297 & 1.81 & 0.0744 & 0.07838117 & \\
X12 & -0.06048629 & -0.77 & 0.4425 & 0.07838117 & \\
\hline
\end{tabular}




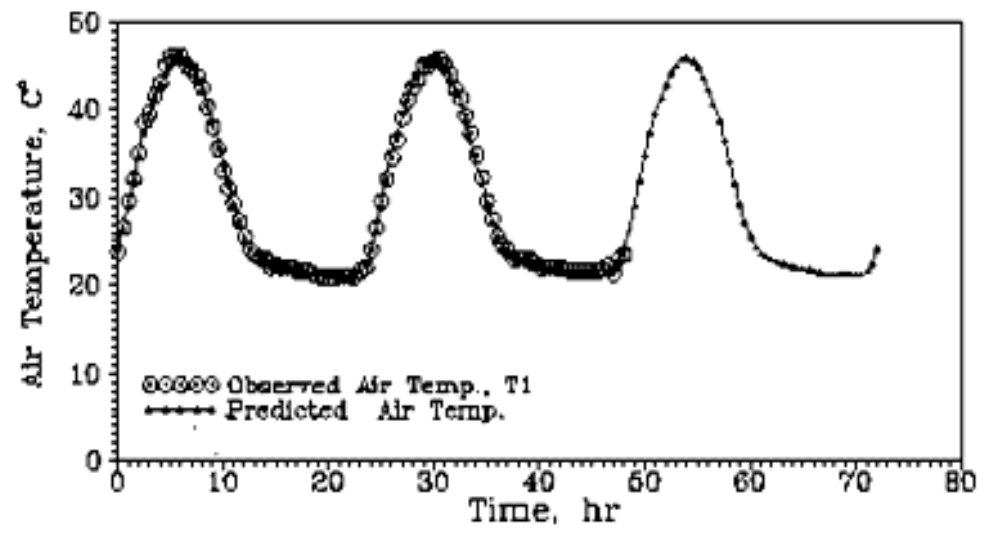

Figure (4): Measured and predicted (fitted) temperature at the inlet of the limestone-bed; $\mathrm{T} 1$

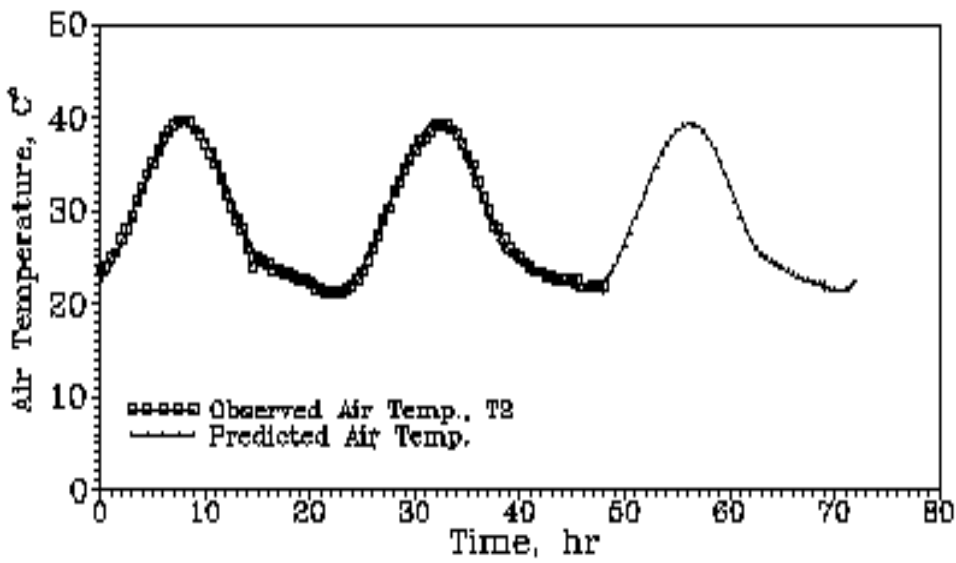

Figure (5): Measured and predicted (fitted) temperature at the middle of the limestone-bed; $\mathrm{T} 2$.

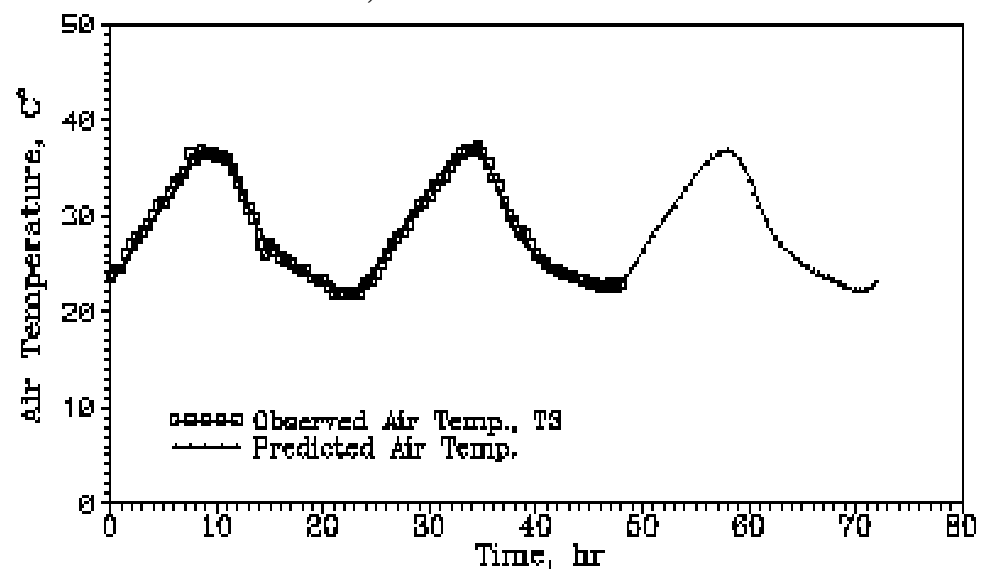

Figure (6): Measured and predicted (fitted) temperature at the outlet of the limestone-bed; T3. 
Table (12): The correlation analysis for variables T3 and Tout computed from limestone bed characteristics.

\begin{tabular}{llllll}
\hline Variable & N & Mean & Std Dev & Minimum & Maximum \\
\hline $\mathrm{T}_{\text {out }}$ & 388 & 29.795 & 7.384 & 20.803 & 42.4656 \\
\hline $\mathrm{T} 3$ & 388 & 28.485 & 4.9741 & 21.750 & 37.2500 \\
\hline
\end{tabular}

Pearson Correlation Coefficient, $\mathrm{r}$, between $\mathrm{T}_{\text {out }}$ and $\mathrm{T} 3=0.90287$

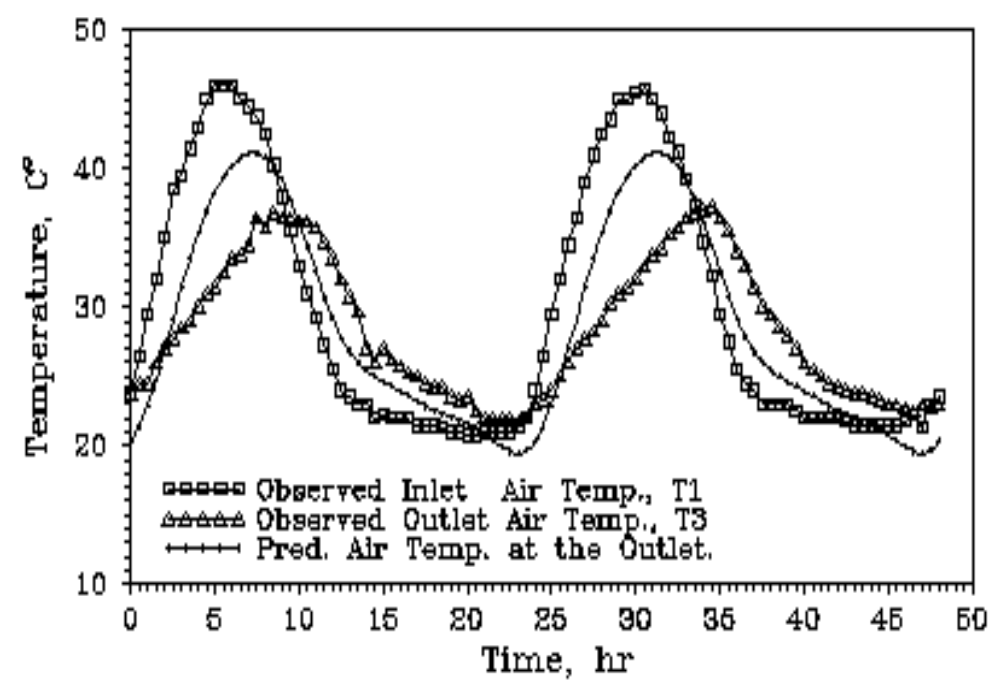

Figure (7): The temperature distribution of the inlet, T1 and the outlet, $\mathrm{T} 3$, of the limestone-bed as well as temperature distribution of $\mathrm{T}_{\text {out }}$ that calculated by the model.

\section{CONCLUSIONS}

From the obtained results, it could generally conclude that:

1- A mathematical model was established and developed to predict the discharge air temperature variation with time.

2- A mathematical equation could be obtained and it was powerful to express the performance of the bed-rock.

3- Good agreement was found between the observed and predicted (fitted) data of air temperature at any rock-bed height. Therefore, the use of the system characteristics and Fourier series was not only successful to predict the temperature distribution at any rock-bed height but also to compute the exponential decay coefficient (A) and the lag phase coefficient (B). 
4- The difference between the mean air temperature for the inlet and outlet of the rock bed was found to be insignificant. The correlation coefficient between the outlet temperature and the computed temperature by the model was above 0.90 .

\section{REFERENCES}

Abdel-Ghaffar, E. 1980. Steady periodic heat transfer in a rock bed exposed to sinusoidal air temperature variation. Ph.D. Dissertation at Iowa State Univ., Ames, Iowa, U.S.A.

Abdel-Ghaffar, E. 1986. Rock beds heat storage for solar heated air. Misr. J. Ag. Eng., 3 (3): 33- 42.

Abdel-Ghaffar, E. 1996. Air temperature in a limestone bed exposed to solar heated air. Misr. J. Ag. Eng., 13 (4): 141-154.

Ahmet Kürklü, Sefai Bilgin and Burhan Özkan, 2002. Study on the solar energy storing rock-bed to heat a polyethylene tunnel type greenhouse.

Augustus, M. L. and Kumar, S., 2007. Evaluation of a solar-biomassrock bed storage drying system. Proceedings of ISES World Congress 2007 (Vol. I-Vol. V). Solar Energy and Human Settlement. Energy Field of Study, Asian Institute of Technology, P.O. Box 4, Klong Luang, Pathumthani, 12120, Thailand.

Bouhdjar, A., M. Belhamel, F.E. Belkhiri, and A. Boulbina, 1996. Performance of sensible heat storage in a rock bed used in a tunnel greenhouse. In: Proc. World Renewable Energy Congress, p. 724728

Bouhdjar, A., A. Boulbina, 1990. Proc Congress Energy and the Environment, Reading, UK, p. 23-25.

Bredenbeck, H., 1984. Rock bed storage inside of greenhouses. Acta Horticulturae 1984; 148. Energy in Protected Cultivation, III, p. 739-744.

Bredenbeck, H., 1987. Energy saving greenhouse system with solar energy and rock bed storage. In: Von Zabeltitz C, editor. Greenhouse heating with solar energy. FAO, p. 195-200.

Chandra, P., L.D. Albright, and G.E. Wilson, 1981. Pressure drop of unidirectional air flow through rock beds. Transactions of the ASAE; $1010-1013$. 
Chandra, P., and D.H. Willits, 1981. Pressure drop and heat transfer characteristics of air-rock bed thermal storage systems. Solar Energy 27 (6) pp. 547-553.

Eshleman, W. D., C. D. Baird, and D.R. Mears, 1977. A numerical Simulation of heat transfer in rock beds. Proceedings of the International Solar Energy Society Conf. 770603-PI, Orlando, Florida. Vol. 2, sec. 17: 21-25.

Fujii, I., 1977. Thermal stress and heat storage capacity in sphere heated by fluid having varying temperature. Bulletin of JSME 20, No. 149: 1389-1395.

Garzoli, K.V., 1989. Design of rock bed for greenhouse energy storage. Acta Horticulturae 257, pp. 21-28.

Hughes, P., S. Klien and D. J. Close, 1976. Packed bed thermal storage models for solar air heating and cooling system. Trans. of the ASME, Journal of Heat transfer 98. No. 2: 336-338.

Lattman, H., and E. Sliva. 1970. Heat Transfer, 4th Int. Conf. Vol. 7, Paris, France.

Löf, G. O. and Hawley 1948. Unsteady state heat transfer between air and loose solids. Industrial and engineering chemistry 40: 10611070.

Packer, B. F., G. M. White, and C. D. Arnold, 1980. Pressure drop and heat transfer in crushed limestone. Transaction of the ASAE. 23(2): 443- 448.

Paksoy, HÖ, A. Basçetinçelik, and H. Öztürk, 1995. Energy storage and underground energy stotage systems. In: Proc 5th Turkish-German Energy Symposium, p. 151-160 (in Turkish).

Riaz, M., 1977. Transient analysis of packed bed thermal storage systems. Solar Energy Journal 121: 123-128.

Santamouris, M., C.A. Balaras, E. Dascalaki and M. Vallindras, 1994. Passive solar agricultural greenhouses: a worldwide classification and evaluation of technologies and systems used for heating purposes. Solar Energy 53 (5), pp. 411- 426.

Schumann, T.W., 1929. Heat transfer: a liquid flowing through a porous Prism. Journal of the Franklin Institute 208 No. 1245-29: 405- 416. 
Smith, J. R., E. A.M. Abdel-Ghaffar and D. S. Bundy, 1984. Response of a rock bed to a periodic temperature variation. Trans. of the ASAE, vol. 27, No. 4, P: 1163-1172.

Walton, L.R., W.H. Henson, S.G. McNeill and J.M. Bunn, 1979. Storing solar energy in an underground rock bed. Trans. of the ASAE; 1202-1207.

Willits, D.H. and M.M. Peet, 1987. Factors affecting the performance of rock storages as solar energy collection/storage systems for greenhouses. Trans. of the ASAE 30 1, pp. 221-232.

Wylie, C. R., 1975. Advanced engineering mathematics. McGraw- Hill Bk. Co., N.Y.

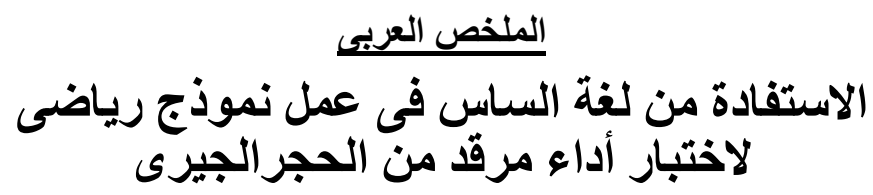

عزت عبد المنعم عبد الغفار** خيرى مصباح اسماعيل*** محمد أبو الحمد رشوان

من المعروف أن عملية تسخين الهواء باستخدام المجمعات الثمسية عادة ما يكون فيها تباين

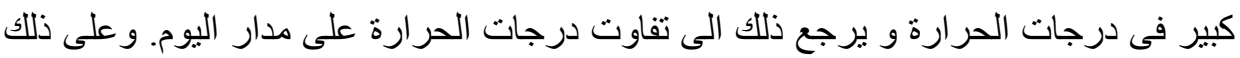

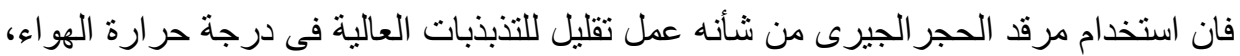
وبالتالى أمكن استخدام مرقد الحجر الجيرى فى تخزين الحرارة المتجمعة خلال ساعات النهار للاستفادة بها خلال ساعات الليل. و على ذلك فان الهدف الرئيسى من هذا البحث هو عمل نموذج رياضى لمرقد الحجرالجيرى

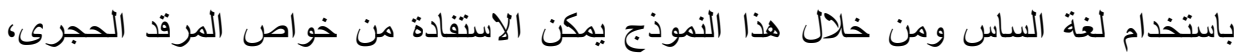

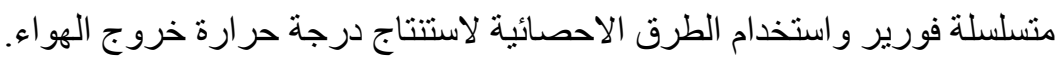
وقد تم تطوير برنامج كومبيوتر لتحقيق هذا الغرض وقد استخدم معدل هواء مدفوع للمرقد

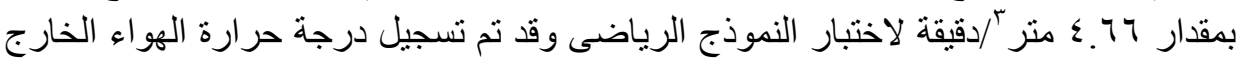

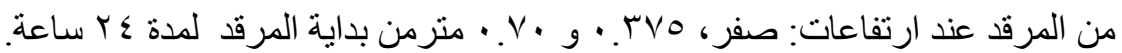
وقد وجد أن متسلسلة فورير أكثر كفاءة فى استنتاج درجة حرارة الهواء عند ألى أى ارتفاع للمرقد

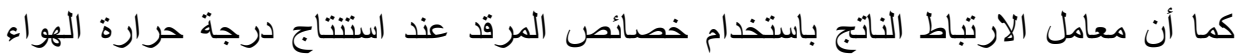

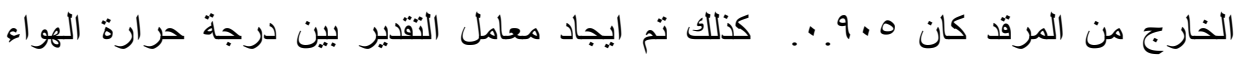

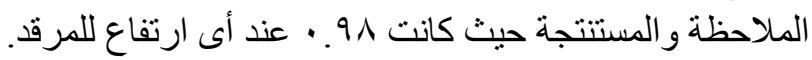

** أستاذ بقسم الهندسة الزراعية والنظم الحيوية ـ كلية الزراعة ـ جامعة الإسكندرية.

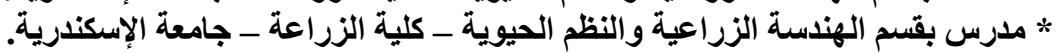

